\title{
The Fine Structure of the Human Ovarian Hilus Cells
}

\author{
TOMIHIDE NISHIDA*, SHIGEAKI IWANAGA*†, KAIJI SATO* \\ AND MASAHIRO MURAKAMI* \\ Department of Anatomy* and Obstetrics and Gynecology ${ }^{\dagger}$, Kurume University School \\ of Medicine, Kurume, 830 Japan
}

Received for publication July 23, 1984

\begin{abstract}
Summary: The ovarian hilus cells from a female patient, 77 years of age, have been observed by light and transmission electron microscopy. The ovarian hilus contains some collagenous fibers, blood vessels and nerve fibers. Hilus cells with a polygonal shape are found in clusters or scattered in the ovarian hilus. The nuclei are nearly round and contain dominant nucleoli. The most prominent cytoplasmic organelle of the hilus cell is an extensively developed smooth endoplasmic reticulum (ER) which is characteristic of steroid secreting cells. The form of the smooth ER is either a network of randomly interconnected tubules or parallel, concentric lamella. A large number of mitochondria with tubular cristae, well-developed Golgi complexes, lipid droplets and lipofuscin granules are in this cell. In addition, rod-shaped crystalline structures, similar to Rienke's crystal, are frequently observed. This fine structure indicates that the ovarian hilus cells are quite similar to steroid producing cells, especially mature Leydig cells in the human testis. The hilus cells are located near myelinated or unmyelinated nerve fibers. The ovarian hilus cells and myeilnated nerve fibers may have an intimate relationship. In the interstitial tissue there are abundant capillaries with fenestrated endothelial cells. This observation indicates that the ovarian hilus cell has an important endocrine function even at an old age.
\end{abstract}

Key words : ovary - ovarian hilus cells - ultrastructure - Reinke's crystal nerve fibers

\section{Introduction}

In the hilus of the human ovarium and in the mesovarium, groups of large epithelioid cells are closely associated with blood vessels and unmeyeilinated nerve fibers. These epithelioid cells were considered to be paraganglion cells or chromaffin cells (Bucura, 1907; Winiwarter, 1910; Neumann, 1928). In 1922 and 1923, Berger reported that they were morphologically similar to the Leydig cells in the human testis and called them sympathicotropic cells because they were always closely related to unmyelinated nerve fibers. Kohn
(1928) has supported these reports and referred to these cells as extraglandular Leydig cells. Thereafter, the view of Berger (1922 and 1923) has been accepted by many investigators, and these cells have been classified as ovarian hilus cells.

The ovarian hilus cells are rich in lipid and lipochrome pigments and contain cytoplasmic crystals apparently identical to those of Reinke. They are present at birth and can be identified within the first year after birth. From one year to the age of puberty they are absent or extremely difficult to observe, however they become prominent during pregnancy (Brannan, 
1927; Dhom, 1954 and 1955). They respond to stimulation by chorionic gonadotropin (Sternberg 1949). Tumorous growth and hyperplasia of these cells are associated with the clinical signs of defeminization and virilization (Sternberg, 1949). Watzka (1957) has briefly reviewed the morphology of hilus cells. The characteristics and appearance of these cells indicate that the ovarian hilus cells are similar to human testicular Leydig cells from morphological, functional and embryological aspects. However, the ultrastructure of human ovarian hilus cells has not been described except in a short report by Brandau et al. (1974).

The aims of the present study are to examine the fine structure of the ovarian hilus cells in the human female by transmission electron microscopy (TEM) and to clarify the functional relationship between hilus cells and nerve fibers.

\section{Material and Methods}

An intact ovary was obtained from a human female, 77 years of age, in the course of the surgical extirpation of uterine cervical cancer. The hilus of the ovary was removed and cut into small pieces. The small specimens were fixed with $2.5 \%$ glutaraldehyde-formaldehyde for 2 hours, rinsed with phosphate buffer, post fixed in $1 \% \mathrm{OsO}_{4}$ buffer for 2 hours, dehydrated in a series of acetone, and embedded in Epok 812. The sections were cut on a Porter-Blum ultramicrotome and observed by $\mathrm{Hu}-12 \mathrm{As}, \mathrm{H}-500$ and JEM $100 \mathrm{~S}$ electron microscope after staining with lead and uranyl acetate. The semithin sections, about $1 \mu \mathrm{m}$ thick, were stained with toluidine blue for light microscopy.

\section{Results}

\section{Light microscopic observations}

The ovarian hilus in the human fe- male is a part of the loose connective tis sue which contains many blood vessels and nerve fibers. In this tissue there are clusters of hilus cells with an epithelioid appearance. Many of the hilus cells are found in groups (Fig. 1a). The nucleus of the hilus cell is spherical in shape. The cytoplasm is well stained with toluidine blue, and contains many granular lipochrome pigments and rod-shaped crystalline bodies, like those of Reinke (Fig. 1b). The hilus cells are often in close contact with nerve fibers with or without myelin sheaths. The nerve fibers are occasionally seen invading the cluster of hilus cells (Fig. $2 \mathrm{a}$ and $\mathrm{b}$ ).

\section{TEM observation}

The hilus cell has various shapes such as polygonal, oval or rectangular, and is $20-30 \mu \mathrm{m}$ in diameter. The cell surface has irregular processes. The nucleus of the hilus cell is about $10 \mu \mathrm{m}$ in diameter, nearly round in contour, and usually located excentrically. The nucleus is composed of a moderately dispersed euchromatin, a small amount of heterochromatin and prominent nucleoli. At low magnification lipofuscin granules of various sizes and organelles are scattered throughout the cytoplasm (Fig. 3). In some areas cell membranes between adjacent cells are differentiated to form gap junctions. The plasma membrane of individual hilus cells facing the connective tissue is incompletely surrounded by a thin basement membrane (Figs. 4 and 5).

The most prominent cytoplasmic organelle of the hilus cell is the extensively developed smooth endoplasmic reticulum (smooth ER) which is characteristic of steroid secreting cells. In the majority of the cells, the smooth ER is a network of interconnecting tubules and is compactly distributed throughout the cytoplasm (Figs. 6 and $7 \mathrm{a}$ ). In some of the cells, the tubules of the smooth ER are arranged in parallel, and there are concentric lamellae around the tubular smooth ER. Both types 
of ER interconnect with each other (Fig. 7b). A few tubules of the rough ER are continuous with lamellae of the smooth ER in the peripheral portion of the cytoplasm (Fig. 5).

The cytoplasm also contains lipid droplets of variable number. The closely packed smooth ER is often organized around the lipid droplets (Fig. 5 and 6).

Mitochondria are abundant in the cytoplasm of the hilus cell. They are generally oval or rod shaped, but some have bizarre shapes. The mitochondrial cristae are frequently tubular instead of lamellar. The matrix is low in density, and occasionally contains spherical, dense mitochondrial granules (Fig. 8).

The Golgi complex of the hilus cells is well developed in the juxtanuclear region of the cytoplasm. The element of the Golgi complex consists of closely packed flat lamellae, small vesicles and large vacuoles.

No secretory contents appear in the Golgi component. In addition, coated vesicles commonly exist in association with the Golgi complex (Fig. 9).

Crystals corresponding to the crystal of Reinke in human testicular Leydig cells occur in the cytoplasm of the ovarian hilus cells. The crystals are present in many, but not all, of the hilus cells. They vary considerably in number, in contour and in size. Their form is usually irregularly polygonal but sometimes hexagonal or rectangular. Fig. 10 shows an irregular-shaped crystal. The configuration of the crystalline subunit varies depending upon the direction of the section. In an appropriate section, the regular parallel internal pattern of the hexagonal crystal can be seen (Figs. $10 \mathrm{~b}$ and $\mathrm{c}$ ). Fibrous structures are occasionally found in the cytoplasm and even within the crystal. This structure may be related to the crystal formation (Figs. 10a and 11).

Many nerve fibers are closely associated with the hilus cells. These fibers include both myelinated and unmyelinated nerve fibers enclosed by a Schwann's sheath. Some are surrounded by a perineurium while others are not. The extremely thin perineurium which is located near the hilus cells is composed of one or two layers of perineural cells. The perineural cells contain many pinocytotic vesicles and a junctional complex, and are characterized by the presence of a basement membrane on the entire surface of the cytoplasmic membrane. Occasionally the perineurium envelopes both the hilus cells and the myelinated nerve fiber (Fig. 12).

The nerve ending is situated near the hilus cell in rare cases. The axon of the nerve fiber which is invested with Schwann cells is located $60 \mathrm{~nm}$ from the hilus cell membrane. Many synaptic vesicles consisting of large cored vesicles and small clear vesicles have accumulated predominantly on the side which is presynaptic to the hilus cell (Fig. 13).

There are also abundant blood capillaries near the cluster of hilus cells. Two types of capillaries can be discerned; one is the fenestrated capillary and the other is the continuous capillary. The fenestrated capillary is more frequently observed (Fig. 14).

\section{Discussion}

The human ovarian hilus cells described in this study have abundant smooth ER, mitochondria with tubular cristae, lipid droplets and a crystalline structure like Reinke's crystal. These ultrastructural findings are identical with those of the mature testicular Leydig cells in the human (Fawcett and Burgos, 1956, 1960; Yamada, 1965; de Krester, 1967a; Nagano and Ohtsuki, 1971; Christensen, 1975).

The smooth ER of the hilus cell appears sometimes vesicular, but this may be an artifact from the tissue preparation, as in the case of the Leydig cells of the guinea pig (Christensen, 1965). In the cytoplasm 
of the hilus cells, the majority of the smooth ER is tightly packed with the tubular network as reported for the cytoplasm of the human Leydig cells (Yamada, 1965). The smooth ER of the hilus cell varies in contour according to the degree of cell development. It has been reported that the variation of $\mathrm{ER}$ may reflect different functional levels in the life cycle of each cell (Fawcett and Burgos, 1960; Yamada, 1965). On the other hand, concentric lamellae of the smooth ER are found enclosing the tubular ER which is randomly dispersed and is often continuous with the rough ER. It has been suggested that they can transform from the rough type to the smooth type. In rats administered HCG, Murakami and Tonutti (1966) have concluded that the formation of concentric lamella of the smooth ER of the testicular Leydig cells, indicates the activation of hormonal production. On this basis the ovarian hilus cells observed in this study are assumed to produce hormones at a higher rate. It is, however, unclear in the present study what type of steroid hormone is synthesized in the hilus cells even though they contain the same cell organellae as the Leydig cells of the human testis.

Fawcett and Burgos (1956 and 1960) first demonstrated the fine structure of the crystal of Reinke in human testicular Leydig cells. The internal pattern of the crystal varied depending upon the angle of the crystalline section. Yamada (1965) has described a regular hexagonal internal structure in suitable sections, possibly when the plane of section is vertical to the plane of the crystal. Nagano and Ohtsuki (1971) have demonstrated that when the sectioned crystal is rectangular in contour the internal structure displays a repetition of parallel lines perpendicular to the long axis of the crystal. The crystal in the cytoplasm of hilus cells has the same ultrastructural features as the crystal of human Leydig icells. The presence of the crystal in the hilus cells is an obvious difference from other steroid producing cells of the ovary.

The aggregation of filamentous structures has been considered to be the structural precursors of crystals in human Leydig cells, however the mechanism of crystal formation is still unknown (Yamada, 1965; Nagano and Ohtsuki, 1971). This structure was observed, not only in the cytoplasm, but also in the nucleus (de Krester, 1967; Yasuzumi et al. 1967). The present study demonstrates that the filamentous structure is also included in the crystal.

Lipofuscin granules in the cytoplasm of the hilus cells can be utilized as a criteria for aging, as they are used in the human Leydig cells. In light microscopic picures, lipofuscin granules appear as brown pigment. As a result, the ovarian hilus cells were initially mistaken for chromaffin cells (Watzka, 1957).

Furthermore, the other aspect of the hilus cells which indicated that they were part of a chromaffin system is the close relationship between the cells and unmyelinated nerve fibers (Watzka, 1957). A number of early investigators have noted that the hilus cells appear scattered or singly within a nerve trunk and lie between individual unmyelinated nerve fibers (Berger, 1922, 1923, 1928; Brannan, 1927; Kohn, 1928; Neuman, 1929; Sternberg, 1949; Sauramo, 1954; Dohm, 1954, 1955; Watzka, 1957). A similar morphological relationship of the human testicular Leydig cells and nerve fibers was also observed (Berger, 1922, 1923, 1928; Brannan, 1927; Sternberg, 1949). The significance of this intimate relationship between the hilus cell and nerve fibers has not yet been clarified. Special attention should be paid to the coexistence of hilus cells and myelinated nerve fibers which are enclosed by one or two continuous sheets of flat perineural cells. Generally, nerve cells, Schwann cells, fibrocytes and vascular endothelial cells are observed in the endo- 
neurium (Ochoa and Mair, 1969; Lieberman, 1968). In addition, mast cells and macrophages also appear within the endoneurium during states of inflamation, injury and demyelinization of peripheral nerve fibers (Olsson, 1968; Wisniewski et al. 1969; Olsson and Sjöstrand, 1969). There is no report on the occurrence of other types of cells in the endoneurium. The presence of hilus cells in the endoneurium of the ovarian peripheral nerve fibers is very characteristic in this study.

The nerve ending is contiguous with the hilus cell. This suggests a close functional relationship between them. However, in the present study the functional relation of the nerve to the hilus cells is not clarified. Further investigation will be necessary.

The blood capillaries of the testicular interstitial tissue in the human are nonfenestrated. With increasing age, the endothelial cell and the surrounding basement membrane become thicker, resulting in a reduction of the functional activity of the interstitial cells (Murakami, 1970). Conversely, in the ovarian hilus the capillary endothelial cells have fenestrations with normal basement membranes. This feature indicates that the hilus cell can maintain an active endocrine function, even in old age.

\section{References}

Berger, L. (1922). Existence de glandes sympathicotropes dans l'ovaire et le testicule humains; leurs rapports avec la glande interstitielle du testicule. Acad. des sciences, 175, 907-909.

Berger, L. (1923). La glande sympathicotrope du hile de l'ovaire: ses homologies avec la glande interstitielle du testicule. Les rapports nerveux des deux glandes. Archives d'Anatomie, d'Histologie et d'Embryologie, 2, 255306.

Berger, L. (1928). Sympathicotrope Zellen im Eierstock und ihre neurokrine Funktion.
Virch. Arch. Path. Anat. Phys. Klin. Med. 267, 433-445.

Brandau, H., Brandau, L., Mestwerdt, W. (1974). Endocrine activity in postmenopausal ovaries. Europ. J. Obstst. Gynec. Reprod. Biol. 4, (sup). 187-196.

Brannan, D. (1927). The sympathicotropic cells of the ovary and testis. Am. J. Pathol. 3, 343-353.

CnRistensen, A.K. (1965). The fine structure of testicular interstitial cells in guinea pigs. J. Cell Biol. 26, 911-935.

Christensen, A.K. (1975). Leydig cells. In Handbook of physiology, Endocrinology V. ed. R. G. Greep and E. B. Astwood, p. 57-94. Washington: Am. Pysiol. Soc.

Doнм, G. (1954). Morphologische, quantitative und histochemische Studien zur Funktion der Hiluszellen des Ovars. Zeit. Geburtshilfe Gynäkologie. 142, 182-228.

Doнм, G. (1955). Morphologische, quantitative und histochemische Studien zur Funktion der Hiluszellen des Ovars. Zeit. Geburtshilfe Gynäkologie. 142, 288-313.

Fawcett, D. W. and Burgos, M.H. (1956). Observation on the cytomorphosis of the germinal and intersitial cells of the human testis. In Ciba Foundation Colloquia in Aging. vol. 2 ed. G. E. W. Wolstenholme and E.C.P. Milar, p. 86-99. Boston, Mass: Little, Brown and $\mathrm{Co}$.

Fawcett, D. W. and Burgos, M. H. (1960) Studies on the fine structure of the mammalian testis. II. The human interstitial tissue. Am. J. Anat. 107, 245-269.

Koнn, A. (1928). U̇ber "Leydigsche Zwischenzellen" im Hilus des menschlichen Eierstockes. (Extraglanduläre Zwischenzellen.) Endokrinologie, 1, 3-10.

de Krester, D.M. (1967a). The fine structure of the testicular interstital cells in men of normal androgenic status. Z. Zellforsch. Mikrosk. Anat. 80, 594-609.

de Krester, D.M. (1967). Changes in the fine structure of the human testicular interstitial cells after treatment with human gonadotrophins. Z. Zellforsch. Mikrosk. Anat. 83, 344-358.

Lieberman, A.R. (1968). The connective tissue elements of the mammalian nodose ganglion. An electron microscope study. Z. Zellforsch. 89, 95-111.

Murakami, M. and Tonutti, E. (1966). Sub- 
mikroskopische Veränderungen der LeydigZellen des Rattenhodens nach Behandlung mit Östrogenen und nach Gonadotropinzufuhr. Endokrinologie. 50, 231-250.

Murakami, M. (1970). Regressive changes in fine structure of the testicular interstitial tissue of the senile and the experimentally treated rats. Advances Andrology. 1, 103-105.

Nagano, T. and Ohtsuki, I. (1971). Reinvestigation of the fine structure of Reinke's crystal in the human testicular interstitial cell. J. Cell Biol. 51, 148-161.

Neumann, H.O. (1929). Die Hiluszellen des Eierstocks - die "sympathicotropen Zellen" L. Bergers. Virch. Arch. Path. Anat. Phys. Klin. Med. 273, 511-523.

Niendorf, F. (1952) Sogenannte Hiluszellen im senilen Ovar. Archiv. für Gynäkologie, 182, 351-358.

OсноA, J. and MaIR, W. G.P. (1969). The normal sural nerve in man. I. Ultrastructure and numbers of fibers and cells. Acta Neuropathol. 13, 197-216.

Olsson, Y. (1968). Mast cells in the nervous system. Int. Rev. Cytol. 24, 27-70.

Olsson, Y. and Suöstrand, J. (1969). Origin of macraphages in Wallerian degeneration of peripheral nerves demonstrated autoradiographically. Exp. Neurol. 23, 102-112.

Olsson, Y. (1971). Mast cells in human peri- pheral nerve. Acta Neurol. Scand. 47, 357368.

Sauramo, H. (1954). Occurrence, function and pathology of ovarian sympathicotropic cells, with special reference to their defferentiation from interstitial or hilus cells. Acta Gynecologica Scandinavica, 33, suppl. 2, 61-81.

SternberG, W. H. (1949). The morphology, androgenic function, hyperplasia and tumors of the human ovarian hilus cells. Amer. J. Path. 25, 493-521.

WAтZKA, M. (1957). Hiluszwischenzellen. In Handbuch der mikroskopischen Anatomie des Menschen, VII-3, ed. Möllendorf W. and Bergmann W. p. 116-120, Berlin Götingen Heidelberg: Springer-Verlag.

WisNiewsKi, H., TERRY, R. D., Whit AKeR, J. N., COOK, S. D. and Dowling, P.C. (1969). Landry-Guillain-Barre syndrome. A primary demyelinating disease. Arch. Neurol. 21, 269-276.

YamAdA, E. (1965). Some observations on the fine structure of the interstitial cell in the human testis as revealed by electron microscopy. Gunma Sym. Endocrinol. 2, 1-17.

YASUZUMi, G., Nakai, Y., Tsubo, I., Yasuda, M. and Sugioka, T. (1967). The fine structure of nuclei as revealed by electron microscopy. IV. The intranuclear inclusion formation in Leydig cells of aging human testes. Exptl. Cell Res. 45, 261-276. 


\section{Explanation of Figures}

Fig. 1. Light micrograph of the ovarian hilus cells. A large number of hilus cells are found as clusters in the connective tissue. The clusters also include the blood vessels (1a). A higher magnification of the hilus cells shows rod-shaped crystals in the cytoplasm (arrow, 1b).

Fig. 2. The hilus cell cluster is often penetrated by myelinated (arrow, 2a) and unmyelinated nerve fibers (arrow, 2b).

Fig. 3. Low power electron micrograph of the hilus cell clusters. The hilus cells are compactly located. Their cytoplasm contains many lipofuscin granules and occasionally a Reinke's crystal (R). $\quad \times 1100$

Fig. 4. The cell membrane of the hilus cells of ten exhibits a special differentiation similar to a gap junction. $\times 76000$

Fig. 5. Near the connective tissue the hilus cells are bordered by a discontinuous basement membrane. $\times 19000$

Fig. 6. Survey electron micrograph of the ovarian hilus cells. They are irregularly outlined and their cell membranes are close to other cell membranes. The nucleus has a dispersed chromatin and the cytoplasm contains well-developed smooth endoplasmic reticulum (smooth ER), scattered mitochondria, Golgi apparatus and lipofuscin granules. $\times 4000$

Fig. 7. High magnification of the hilus cell cytoplasm. The smooth ER is well-developed, consisting of a network of randomly interconnected tubules (7a) and parallel concentric lamellae (7b). The ERs are interconnected in some portions. $7 \mathrm{a} ; \times 42000.7 \mathrm{~b} ; \times 24000$
Fig. 8. The mitochondria contain tubular cristae and electron dense mitochondrial granules in the matrix. $\times 24000$

Fig. 9. Golgi complex of the hilus cell. Golgi vacuoles have no secretory materials. Coated vesicles are associated with the Golgi complex region. $\times 2000$

Fig. 10. Crystal of Reinke in the cytoplasm of the hilus cell. It appears to be polygonal in contour, and a dislocation of the crystal (arrow) is frequently seen. The central portion of the crystal contains an aggregation with a filamentous structure that is probably related to the precursor of the crystal $(10 \mathrm{a})$. Suitable sections of the crystal reveal two types of regular internal structure ( $10 \mathrm{~b}$ and $\mathrm{c}$ ); one is a hexagonal honeycomb pattern $(10 \mathrm{~b})$ and the other is a regularly repeated line, arranged in parallel and perpendicular to the long axis of the crystal (10c). $10 \mathrm{a} ; \times 10000,10 \mathrm{~b} ; \times 100000$, $10 \mathrm{c} ; \times 88000$

Fig. 11. Aggregation of filamentous structures in the hilus cell cytoplasm. $\times 15500$

Fig. 12. The hilus cells and myelinated nerve fibers are surrounded by continuous cell layers of perineurium. Some hilus cells are occasionally seen in the space between perineural cell layers (arrow). $\times 56000$

Fig. 13. The nerve ending is contiguous with the hilus cells for a distance of $60 \mathrm{~nm}$. Many synaptic vesicles composed of large cored vesicles and small clear vesicles are accumulated on the side near the hilus cells. $\times 27000$

Fig. 14. A blood capillary near the hilus cell cluster. The endothelial cell has fenestrations. $\times 8700$ 

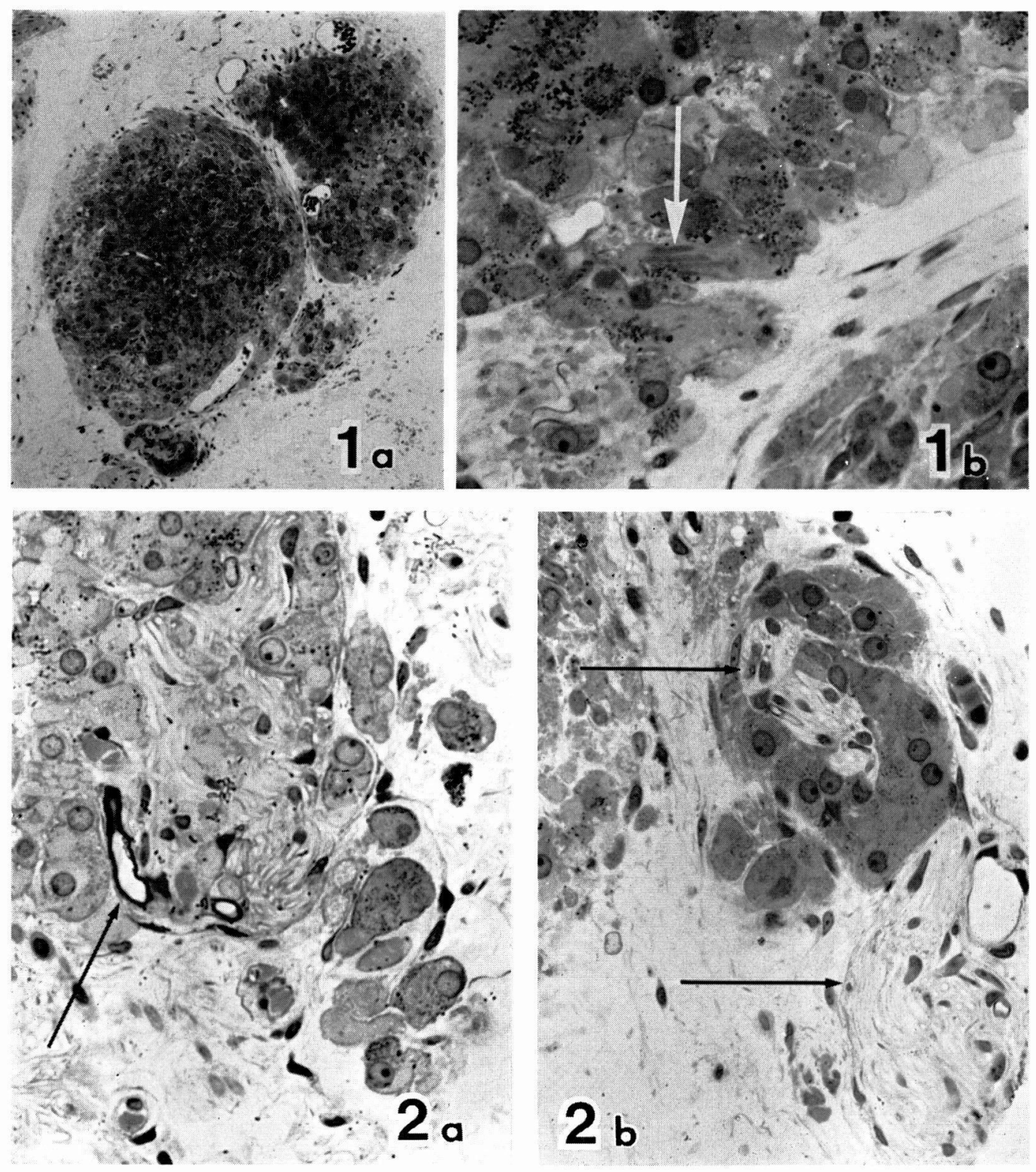


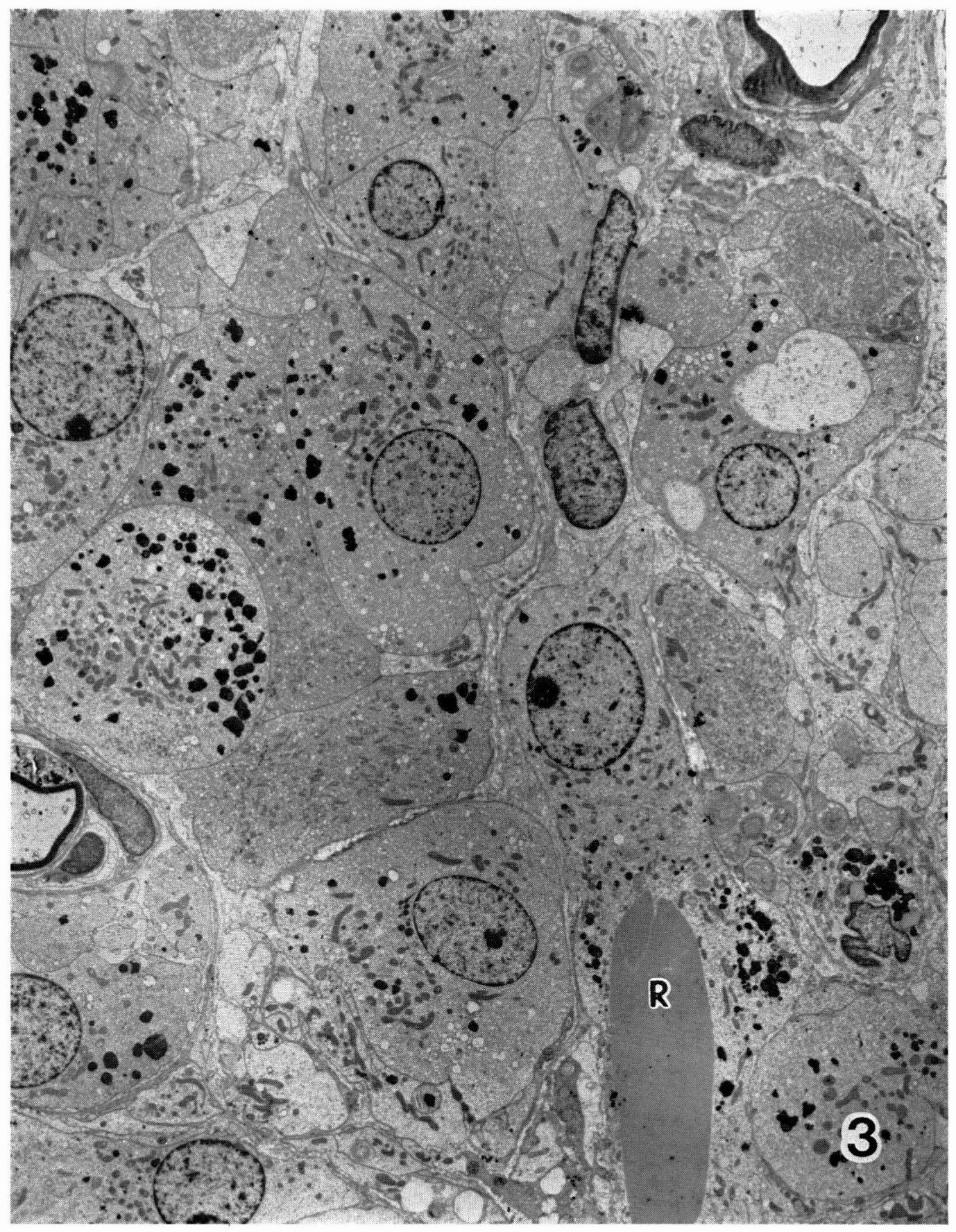



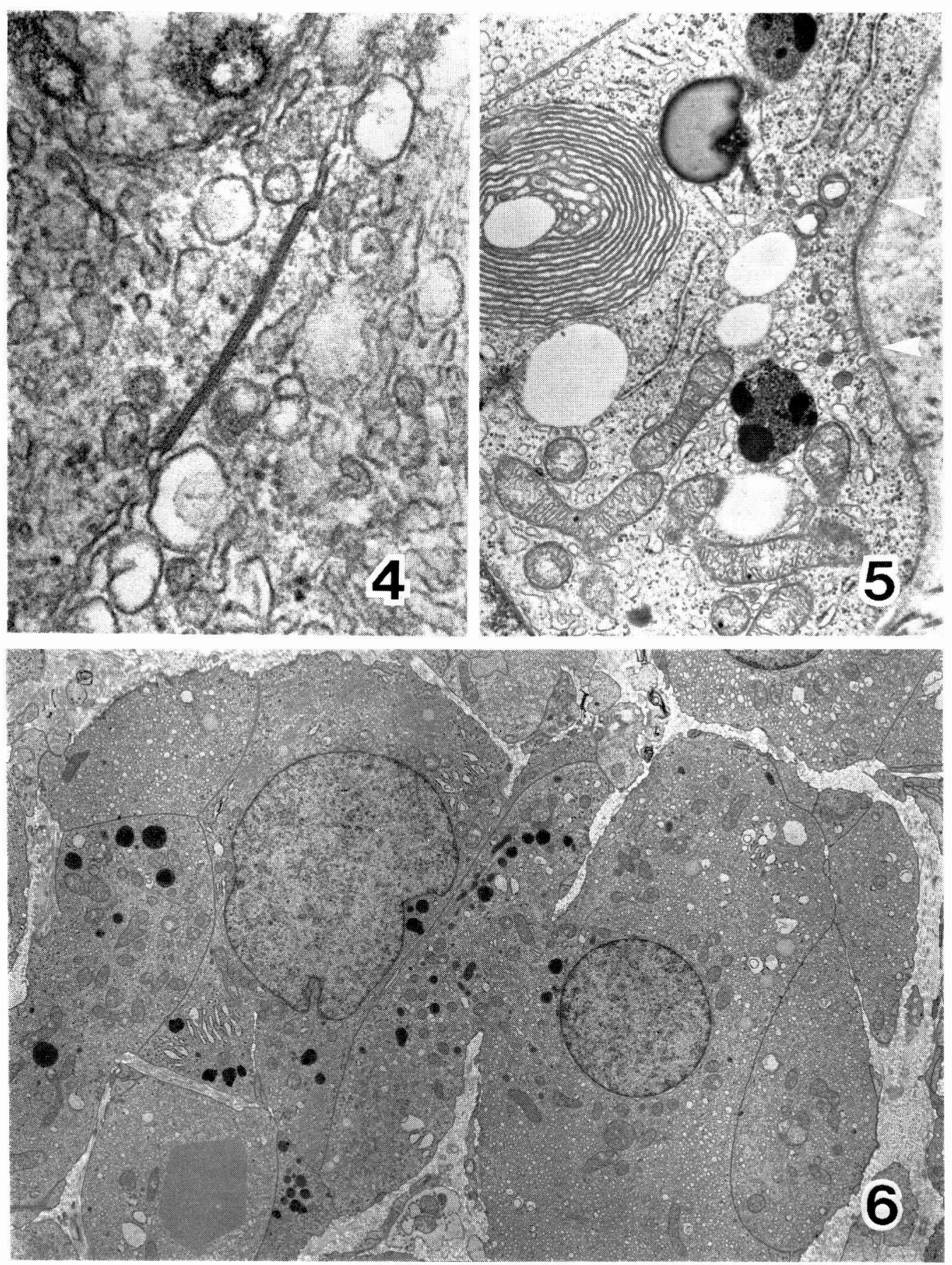

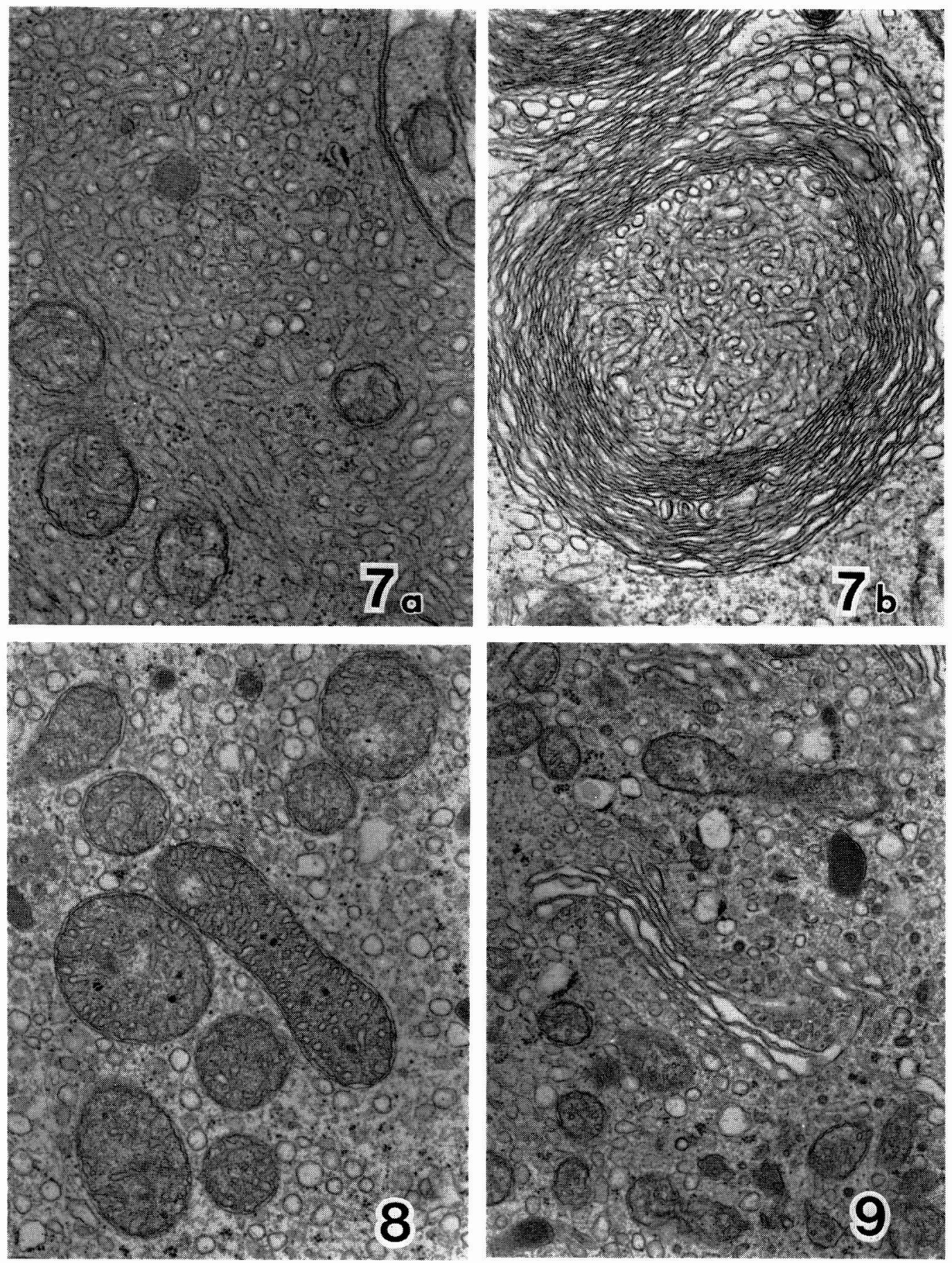

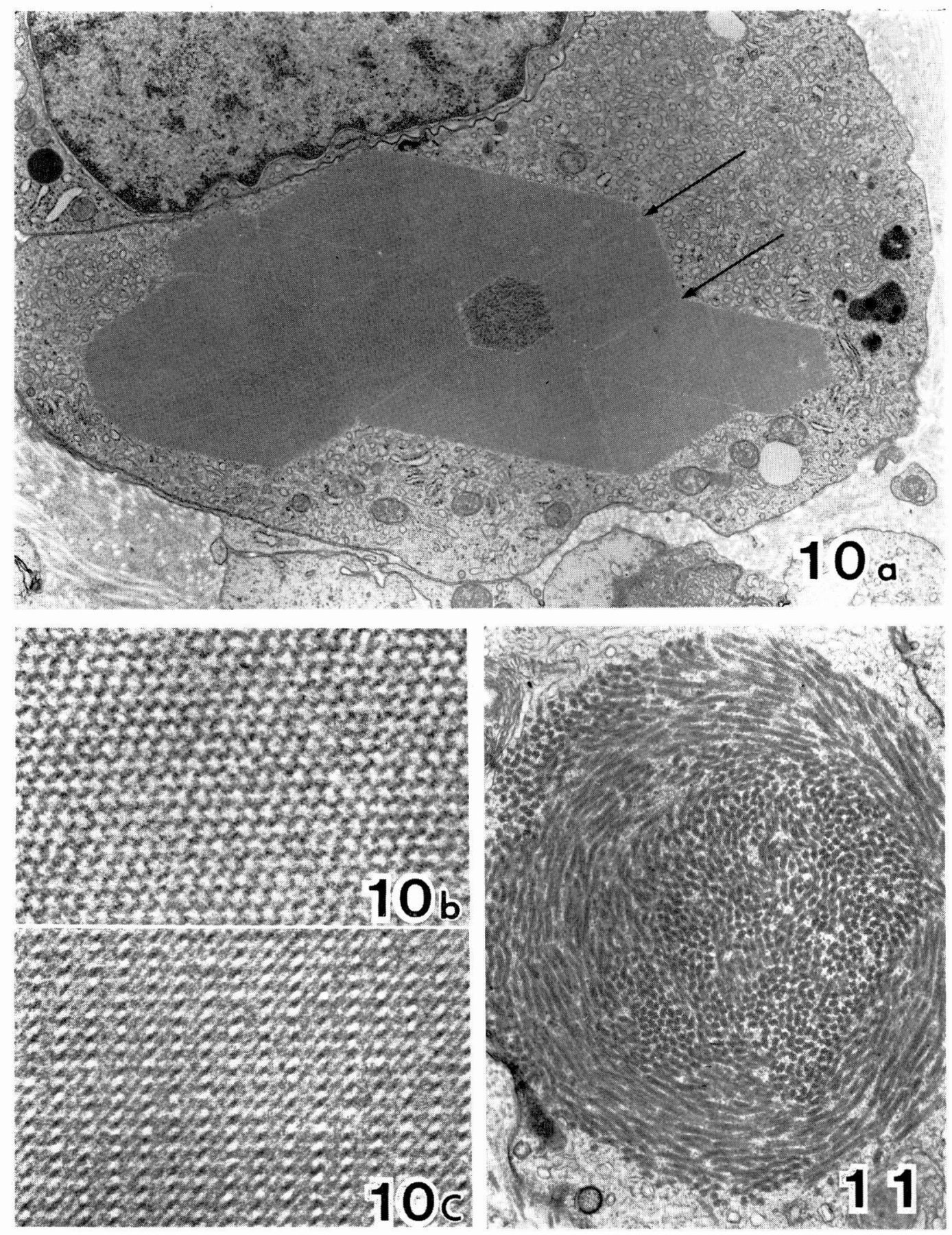


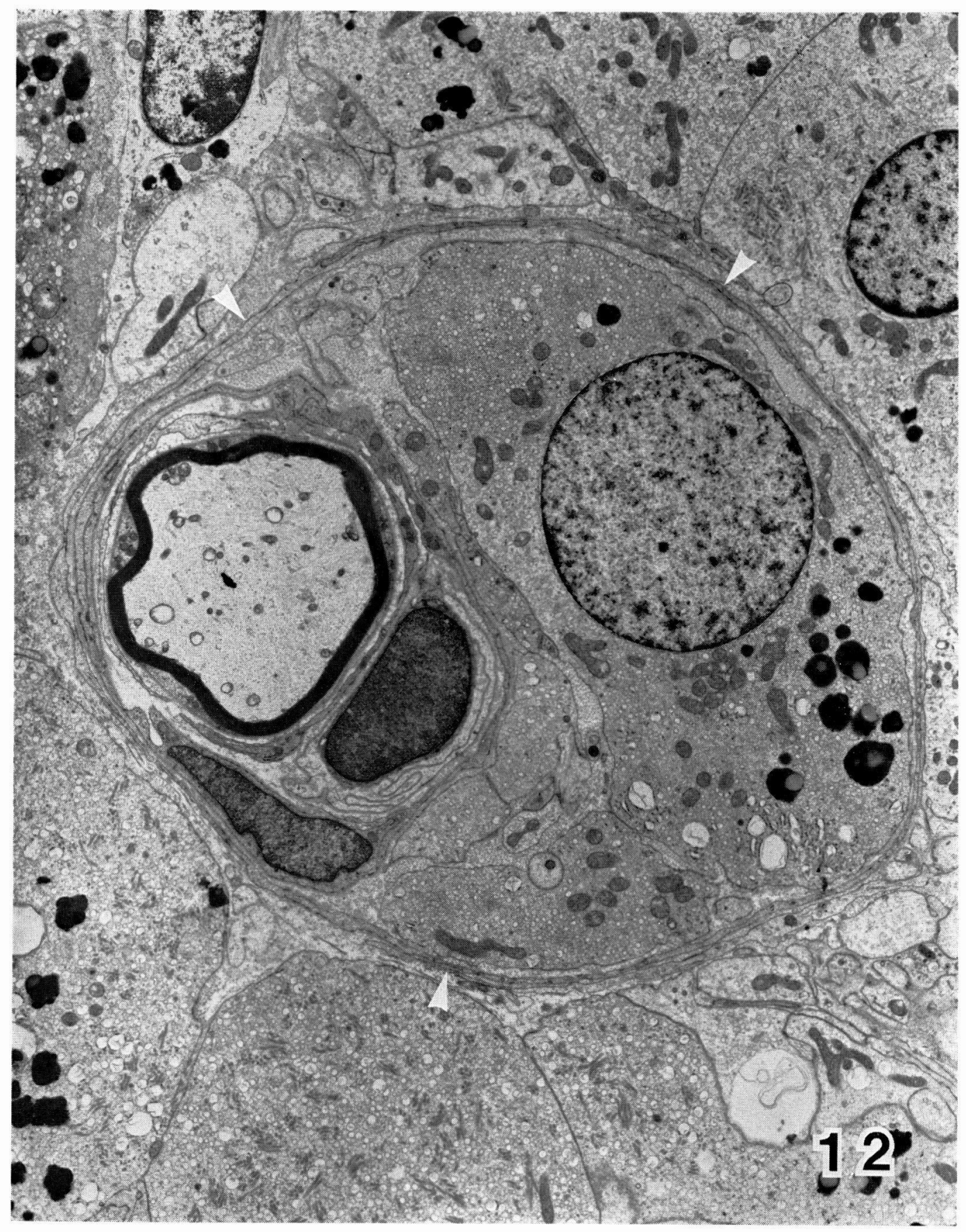



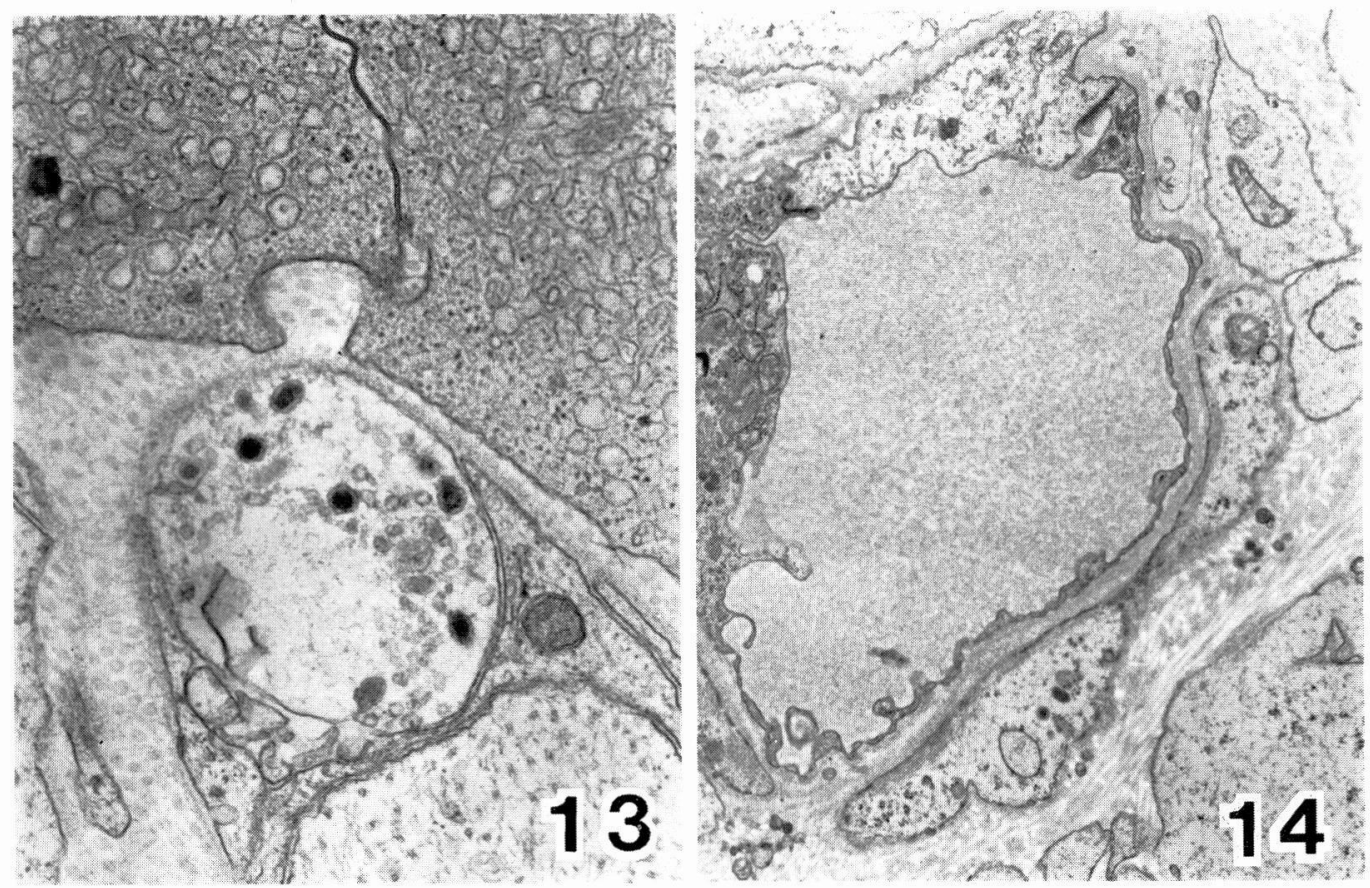